\title{
ANALISIS POTENSI TERAPI SELULER MENGGUNAKAN ADIPOSE- DERIVED STEM CELLS DAN PLATELET-RICH PLASMA DALAM PENANGANAN PENYAKIT ALZHEIMER
}

\author{
Rejoel Mangasa Siagian'1 , Grady Krisandi² \\ 1,2 Program Studi Pendidikan Dokter, Fakultas Kedokteran, Universitas Indonesia
}

\begin{abstract}
Alzheimer's disease as the main cause of dementia cases in the elderly continues to increase along with the growth in the number of elderly people. Diagnosis, prevention, and specifically treatment of Alzheimer's disease need to be further investigated. Research on cellular therapy using adipose-derived stem cells (ADSC) as well as the use of platelet-rich plasma $(P R P)$ biotechnology shows a new and potential treatment method therefore an analytical study is needed regarding its potential as a candidate for Alzheimer's therapy. The review was conducted in accordance with PRISMA guidelines from a number of databases accessed online. From the analysis of literature studies, ADSC and PRP decreased concentrations of amyloid beta $(A \beta)$ peptides, neuron growth and synaptogenesis, activation of microglia with anti-inflammatory phenotypes, increased production of anti-inflammatory cytokines, increased synapse and dendrite stability, increased neuron viability, increased neurogenesis, and decreased neurodegeneration. and cognitive enhancement. The potential of ADSC and PRP is quite promising, although there are not many PRPs that have studied their potential in Alzheimer's disease. Further studies on these two bioactive factors are needed to increase the potency and possible combination of ADSC and PRP therapy for Alzheimer's disease.
\end{abstract}

\begin{abstract}
Abstrak
Alzheimer sebagai penyakit penyebab utama dari kasus demensia pada lansia terus meningkat seiring dengan pertumbuhan jumlah penduduk usia lanjut. Diagnosis, pencegahan, dan secara khusus penanganan penyakit Alzheimer perlu diteliti lebih lanjut. Penelitian terapi seluler dengan menggunakan sel punca adipose-derived stem cell (ADSC) serta penggunaan bioteknologi platelet-rich plasma (PRP) menunjukkan sebuah penanganan dengan metode baru dan potensial oleh karennya dibutuhkan kajian analisis terkait potensi sebagai kandidat terapi Alzheimer. Kajian dilakukan sesuai dengan panduan PRISMA dari sejumlah database yang diakses daring. Dari hasil analisis studi literatur, ADSC dan PRP penurunan konsentrasi peptida amiloid beta $(\mathrm{A} \beta)$, pertumbuhan neuron dan sinaptogenesis, aktivasi mikroglia dengan fenotipe antiinflamasi, peningkatan produksi sitokin antiinflamasi, peningkatan stabilitas sinaps dan dendrit, peningkatan viabilitas neuron, peningkatan neurogenesis, dan penurunan neurodegenerasi.dan peningkatan kognitif. Potensi ADSC dan PRP cukup menjanjikan walaupun PRP masih belum banyak yang meneliti potensinya pada penyakit Alzheimer. Studi lebih lanjut mengenai kedua faktor bioaktif tersebut diperlukan untuk meningkatkan potensi serta kemungkinan kombinasi terapi ADSC dan PRP untuk penyakit Alzheimer.
\end{abstract}

Keywords: alzheimer, adipose-derived stem cells, stromal vascular fraction, platelet-rich plasma

\section{PENDAHULUAN}

Penyakit degeneratif pada sistem saraf pusat yang paling umum dialami saat usia lanjut adalah Alzheimer, penyakit yang pertama kali diidentifikasi oleh seorang psikiater yang juga pakar neurologi berkebangsaan Jerman yaitu AloisAlzheimer pada tahun 1907. Penyakit
Alzheimer menjadi salah satu tantangan dalam pelayanan kesehatan sebagai penyebab utama demensia (pikun), yaitu sebanyak 60- $80 \%$ kasus.

Sejumlah lebih dari 40 juta orang di seluruh dunia diperkirakan akan mengalami demensia dengan jumlah yang terus meningkat. World Alzheimer Report 2015 menunjukkan ada sekitar 556.000 penderita 
demensia dengan prevalensi $2.7 \%$ dengan perkiraan laju peningkatan pada 2040 sebesar 325\%. Kasus demensia yang umumnya terjadi pada lansia $>60$ tahun yang mana seiring peningkatan usia hidup akan terjadi peningkatan pesat kasus demensia terutama Alzheimer sehingga perlu inovasi dalam diagnosis, pencegahan, dan secara khusus penanganannya.

Gejala klinis yang ditunjukkan oleh penderita demensia yaitu penurunan kognitif progresif pada dua atau lebih domain termasuk memori, bahasa, fungsi eksekutif, visuospasial, kepribadian, dan perilaku hingga hilangnya kemampuan aktivitas dasar sehari-hari. Gejala pendukung lainnya adalah kebingungan, interpretasi buruk, gangguan berbicara, agitasi, cenderung penarikan diri, dan kerap berhalusinasi. Diagnosis pasti dalam penegakan penyakit Alzheimer membutuhkan pemeriksaan post- mortem jaringan otak, namun pada pasien hidup diperlukan pemeriksaan cairan serebrospinal dan biomarker dengan positron emission tomography (PET) yang dikombinasikan dengan berbagai kriteria klinis.

Penanganan penyakit Alzheimer saat ini memerlukan berbagai faktor seperti: keterbukaan komunikasi pelayan kesehatan; pendekatan perilaku melalui rutinitas, konsistensi, dan penyederhanaan lingkungan; terapi perilaku kognitif; terapi cahaya; terapi musik; perencanaan tepat waktu akan kebutuhan medis; dorongan pengembangan koneksi para pengasuh; serta intervensi farmakologis. Pengobatan yang tersedia saat ini merupakan golongan inhibitor kolinesterase yang diberikan pada setiap setiap tahap demensia Alzheimer dan memantine untuk penderita pada tahap sedang sampai berat. Terapi tersebut terbukti meningkatkan kualitas hidup pasien bila diberikan pada waktu yang tepat, namun terapi tersebut tidak mampu mengubah perjalanan keparahan penyakit dengan kata lain tidak mampu menurunkan tingkat keparahan yang telah terjadi.

Penyebab Alzheimer secara patologi disebabkan oleh pembentukan senile plaque (SP) yang dibentuk amiloid beta (A $\beta$ ) dan neurofibrally tangles (NFTs) yang disusun oleh tau protein terfosforilasi di hipokampus. Plak amyloid (SP) memiliki sifat yang sangat tidak larut dan dibentuk oleh fibril peptida yang resisten terhadap proteo lisis hasil pembelahan $\beta$ - amiloid (A $\beta)$. Pembentukan $A \beta$ akan memicu gejala klinis yang dimulai dengan pembentukan oligomer amiloid yang sifat neurotoksisitasnya akan memulai kaskade amiloid.Kaskade tersebut meliputi inflamasi local, oksidasi, dan eksitoksisitas (penumpukan glutamate berlebihan), dan hiperfosforilasi tau. Mikroglia dan astrosit akan teraktifkan seiring dengan produksi $\mathrm{A} \beta$ serta memicu reaksi inflamasi dan oksidasi. Penelitian membuktikan bahwa inflamasi terjadi pada jaringan otak penderita Alzheimer akibat aktivasi sistem komplemen dan mikroglia. Kerusakan progresif saraf ini yang kemudian akan menyebabkan kekurangan dan ketidak seimbangan antara berbagai neurotransmitter dan berujung pada defisiensi kognitif seperti yang dialami pasien Alzheimer.

Adipose-derived stem cell (ADSC) merupakan sel punca mesenkimal yang berada pada jaringan adiposa. Pengambilan ADSC dapat dilakukan dengan prosedur invasif yang minimal melalui liposuction, tidak seperti pengambilan sel punca mesenkimal lainnya yang lebih invasif seperti sel punca mesenkimal yang berada pada sumsum tulang. ADSC dimanfaatkan untuk berbagai keperluan terapi regeneratif, 
termasuk penyakit neurodegeneratif seperti Alzheimer, karena memiliki sifat pluripoten, sifat autologous sehingga terhindar dari penolakan imunologis, serta terhindar dari masalah etik dan tumorigenesis. Sifat regenerative ADSC dalam terapi regeneratif ada pada kemampuannya menghasilkan faktor bioaktif berupa eksosom yang mengandung berbagai enzim dan sekresi imunomodulator.

Platelet-rich plasma (PRP) merupakan bioteknologi terbaru yang mudah, murah, tidak invasive, dan memiliki banyak potensi terapeutik, termasuk neuroregeneratif. PRP didapat dengan mengambil darah untuk mendapatkan konsentrat platelet. Konsentrat platelet didapat melalui sentrifugasi darah dan aktivasi menggunakan activator seperti thrombin atau $\mathrm{CaCl}$. Aktivasi PRP akan melepaskan granul alfa intraseluler yang mengandung banyak platelet-rich growth factors (PRGF). PRGF merupakan faktor yang terdiri dari faktor pertumbuhan/growth factors (GF) dan sitokin, antara lain adalah vascular endothelial growth factor (VEGF), insulinlike growth factor (IGF), epidermal growth factor (EGF), platelet-derived growth factors (PDGF), dan transforming growth factor- $\beta \quad$ (TGF- $\beta$ ). PRGF bersifat neuroprotektif serta neuroregeneratif karena berperan dalam melindungi neuron serta sel glia dari apoptosis; meregulasi sekresi neurotransmitter, plastisitas sinaps, dan faktor neurotropik lain untuk memperbaiki lingkungan mikro ekstraseluler neuron sehingga mendukung pertumbuhan dan fungsi neuron23,24; angiogenesis; dan menginduksi sel progenitor neuron untuk berproliferasi, bermigrasi, dan berdiferensiasi menggantikan neuron yang rusak.

Banyak bioteknologi baru telah dikembangkan dengan potensi terapeutik yang beragam. PRP dan penggunaan ADSC memiliki potensi terapeutik yang menjanjikan untuk menangani penyakit Alzheimer. Karena kurangnya kajian pustaka mengenai kedua bioteknologi tersebut terhadap Alzheimer, kajian pustaka ini dibuat dengan harapan dapat menjelaskan potensi serta memberikan informasi yang adekuat untuk melakukan penelitian lebih lanjut dalam bidang tersebut.

\section{METODE}

Tinjauan literatur dilakukan berdasarkan panduan PRISMA statement dari database daring yaitu PubMed, Cochrane, Sciencedirect, Wiley Online Library, dan EBSCOhost dengan kata kunci [(Adipose tissue-derived stem cells) OR (Stromal Vascular Fraction) OR (Platelet-rich plasma) AND (Alzheimer)]. Kriteria inklusi untuk menyaring pustaka, yaitu: studi eksperimental dan randomized controlled trial serta penelitian identifikasi efek terapi Adipose tissue-derived stem cells (ADSC), Stromal Vascular Fraction (SVF), dan Platelet-rich plasma (PRP) pada penyakit Alzheimer. Selain itu, kriteria eksklusi diterapkan berupa: akses artikel berbayar, jenis studi tidak diketahui, studi dengan data yang tidak dapat diekstrak, tidak ditulis dalam Bahasa Inggris, serta artikel review. Selanjutnya data dan ringkasan dari literatur tersebut diekstrak dan di bahas pada Tabel 1.

\section{HASIL DAN PEMBAHASAN}




\begin{tabular}{|c|c|c|c|c|c|c|c|}
\hline No. & $\begin{array}{c}\text { Sumber } \\
\text { Faktor } \\
\text { Bioaktif }\end{array}$ & $\begin{array}{c}\text { Kandungan } \\
\text { Faktor } \\
\text { Bioaktif }\end{array}$ & Subjek & Metode & $\begin{array}{l}\text { Jenis } \\
\text { Studi }\end{array}$ & Hasil & Penulis \\
\hline 1 & hADSC & ADSC-Exo & $\begin{array}{l}\text { Sel } \\
\text { neuron } \\
\text { Alzheimer }\end{array}$ & Kokultur & $\begin{array}{l}\text { in } \\
\text { vitro }\end{array}$ & $\begin{array}{l}\text { 1. Penurunan konsentrasi } \\
\text { A } \beta \\
\text { 2. Modulasi molekul } \\
\text { sinyal apoptosis } \\
\text { 3. Atenuasi apoptosis } \\
\text { 4. Pertumbuhan neuron } \\
\text { dan sinaptogenesis }\end{array}$ & $\begin{array}{l}\text { Lee M, } \\
\text { Ban J, } \\
\text { Yang S, } \\
\text { Im W, } \\
\text { Kim M }\end{array}$ \\
\hline 2 & hADSC & $\begin{array}{l}\text { ADSC-Exo } \\
\text { (NEP) }\end{array}$ & $\begin{array}{l}\text { Cell line } \\
N 2 a\end{array}$ & Kokultur & $\begin{array}{l}\text { in } \\
\text { vitro }\end{array}$ & $\begin{array}{l}\text { 1. Penurunan signifikan } \\
\text { konsentrasi } \mathrm{A} \beta \\
\text { ekstrasel dan intrasel } \\
\text { 2. Peleburan eksosom } \\
\text { dengan cell line } \mathrm{N} 2 \mathrm{a}\end{array}$ & $\begin{array}{l}\text { Katsuda } \\
\text { T, } \\
\text { Tsuchiya } \\
\text { R, } \\
\text { Kosaka } \\
\mathrm{N}, \\
\text { Yoshioka } \\
\text { Y, } \\
\text { Takagaki } \\
\text { K, Oki K, } \\
\text { et al. }\end{array}$ \\
\hline 3 & mADSC & $\begin{array}{l}\text { IL-4 dan } \\
\text { arginase I }\end{array}$ & $\begin{array}{l}\text { Tikus } \\
\text { transgenik } \\
\text { APP/PS1 }\end{array}$ & $\begin{array}{l}\text { Injeksi } \\
\text { intraserebral }\end{array}$ & $\begin{array}{l}\text { In } \\
\text { vivo }\end{array}$ & $\begin{array}{l}\text { 1. Peningkatan } \\
\text { kemampuan kognitif } \\
\text { 2. Penurunan signifikan } \\
\text { deposit peptida } \mathrm{A} \beta \\
\text { pada hipokampus dan } \\
\text { korteks } \\
\text { 3. Aktivasi mikroglia } \\
\text { dengan fenotipe } \\
\text { antiinflamasi pada } \\
\text { otak } \\
\text { 4. Peningkatan kapasitas } \\
\text { degradasi peptida } \mathrm{A} \beta \\
\text { mikroglia }\end{array}$ & $\begin{array}{l}\text { Ma T, } \\
\text { Gong K, } \\
\text { Ao Q, } \\
\text { Yan Y, } \\
\text { Song B, } \\
\text { Huang H, } \\
\text { et al. }\end{array}$ \\
\hline 4 & hADSC & $\begin{array}{l}\text { IL-10, } \\
\text { ADSC- Exo } \\
\text { (NEP) }\end{array}$ & $\begin{array}{l}\text { Tikus } \\
\text { transgenik } \\
\text { APPswe } \\
\text { Tg2576; } \\
\text { cell line } \\
\text { BV2 }\end{array}$ & $\begin{array}{l}\text { Injeksi } \\
\text { intravena; } \\
\text { kokultur }\end{array}$ & $\begin{array}{l}\text { In } \\
\text { vivo } \\
\text { dan in } \\
\text { vitro }\end{array}$ & $\begin{array}{l}\text { 1. hADSC berhasil } \\
\text { menembus sawar } \\
\text { darah otak } \\
\text { 2. Peningkatan } \\
\text { kemampuan spasial } \\
\text { 3. Penurunan konsentrasi } \\
\text { peptida A } \beta \text { dan APP- } \\
\text { CT pada korteks dan } \\
\text { hipokampus } \\
\text { 4. Peningkatan produksi } \\
\text { neprilysin } \\
\text { 5. Peningkatan produksi } \\
\text { sitokin antiinflamasi } \\
\text { IL-10 dan faktor } \\
\text { neurotropik VEGF } \\
\text { 6. Peningkatan stabilitas } \\
\text { sinaps dan dendrit }\end{array}$ & $\begin{array}{l}\text { Kim S, } \\
\text { Chang K, } \\
\text { Kim J, } \\
\text { Park H, } \\
\text { Ra JC, } \\
\text { Kim H, et } \\
\text { al. }\end{array}$ \\
\hline
\end{tabular}




\begin{tabular}{|c|c|c|c|c|c|c|c|}
\hline 5 & hADSC & - & $\begin{array}{l}\text { Tikus } \\
\text { transgenik } \\
\text { Tg2576 }\end{array}$ & $\begin{array}{l}\text { Injeksi } \\
\text { intravena }\end{array}$ & $\begin{array}{l}\text { In } \\
\text { vivo }\end{array}$ & $\begin{array}{l}\text { hADSC berhasil } \\
\text { menembus sawar darah } \\
\text { otak }\end{array}$ & $\begin{array}{l}\text { Ha S, } \\
\text { Ahn S, } \\
\text { Kim S, } \\
\text { Joo Y, } \\
\text { Chong } \\
\text { YH, Suh } \\
\text { Y, et al. }\end{array}$ \\
\hline 6 & SVF & - & $\begin{array}{l}10 \text { pasien } \\
\text { Alzheimer }\end{array}$ & $\begin{array}{l}\text { Liposuction; } \\
\text { injeksi } \\
\text { subgaleal } \\
\text { Ommaya } \\
\text { reservoir }\end{array}$ & $\begin{array}{l}\text { Uji } \\
\text { klinis } \\
\text { fase I }\end{array}$ & $\begin{array}{l}\text { 1. } \quad 8 \text { pasien stabil } \\
\text { dan memiliki } \\
\text { peningkatan kognitif } \\
2 . \quad 3 \text { pasien } \\
\text { memiliki penurunan } \mathrm{P}- \\
\text { tau dan perbaikan rasio } \\
\text { A } \beta \text { terhadap total tau }\end{array}$ & $\begin{array}{l}\text { Duma C, } \\
\text { Kopyov } \\
\text { O, } \\
\text { Kopyov } \\
\text { A, } \\
\text { Berman } \\
\text { M, } \\
\text { Lander E, } \\
\text { Elam M, } \\
\text { et al. }\end{array}$ \\
\hline 7 & PRP & $\begin{array}{l}\text { NGF, } \\
\text { VEGF, IGF- } \\
\text { I, PDGF, } \\
\text { HGF, TGF }\end{array}$ & $\begin{array}{l}\text { Tikus } \\
\text { jantan } \\
\text { transgenik } \\
\text { APP/PS1 }\end{array}$ & $\begin{array}{l}\text { Injeksi } \\
\text { intranasal }\end{array}$ & $\begin{array}{l}\text { In } \\
\text { vivo }\end{array}$ & $\begin{array}{l}\text { 1.Usia dan status } \\
\text { kesehatan tidak } \\
\text { berpengaruh terhadap } \\
\text { potensi efikasi PRP } \\
\text { 2.Penurunan neuron mati } \\
\text { dan peningkatan } \\
\text { viabilitas neuron saat } \\
\text { terpajan peptida A } \beta 42 \\
\text { 3.Peningkatan } \\
\text { neurogenesis } \\
\text { hipokampus } \\
\text { 4.Penurunan } \\
\text { neurodegenerasi }\end{array}$ & $\begin{array}{l}\text { Anitua E, } \\
\text { Pascual } \\
\text { C, Pérez- } \\
\text { Gonzalez } \\
\text { R, } \\
\text { Antequera } \\
\text { D, Padilla } \\
\text { S, Orive } \\
\text { G, et al. }\end{array}$ \\
\hline
\end{tabular}

Catatan: Human adipose-derived stem cells (hADSC), mouse adipose-derived stem cells (mADSC), adipose-derived stem cells-exosome (ADSC-Exo), neural endopeptidase (NEP), interleukin 4 (IL-4), Interleukin 10 (IL-10), stromal vascular fraction (SVF), platelet-rich plasma (PRP), neural growth factor (NGF), vascular endothelial growth factor (VGEF), insulinlike growth factor I (IGF-I), platelet- derived growth factor (PDGF), hepatocyte growth factor (HGF), transforming growth factor (TGF).

Berdasarkan 7 dari 381 studi yang sesuai dengan kriteria inklusi dan eksklusi, 6 studi meneliti potensi ADSC terhadap penyakit Alzheimer dan 1 studi meneliti potensi PRP terhadap penyakit Alzheimer. Klasifikasi intervensi ADSC dapat dibagi menjadi tiga jenis: kokultur ADSC dengan cell line neuron Alzheimer, injeksi intraserebral dan intravena pada model tikus, dan injeksi subgaleal Ommaya reservoir pada subjek PRP hanya ada 1 jenis, yaitu injeksi manusia. Sedangkan, klasifikasi untuk intranasal pada model tikus.
Dari 6 studi potensi ADSC terhadap Alzheimer, hasil utama yang didapat adalah penurunan konsentrasi peptida $\mathrm{A} \beta$, pertumbuhan neuron dan sinaptogenesis, aktivasi mikroglia dengan fenotipe antiinflamasi, peningkatan produksi sitokin antiinflamasi, peningkatan stabilitas sinaps dan dendrit, dan peningkatan kognitif. Dari studi potensi PRP terhadap Alzheimer didapatkan hasil utama berupa peningkatan viabilitas neuron, peningkatan neurogenesis, dan penurunan neurodegenerasi. 
Lee $\mathrm{M}$, et al. melakukan studi in vitro untuk meneliti potensi dari eksosom ADSC (ADSC-Exo) manusia pada kultur sel neuron Alzheimer dan menemukan penurunan konsentrasi peptida $\mathrm{A} \beta$; modulasi molekul persinyalan apoptosis sehingga mengatenuasi apoptosis; dan pertumbuhan neuron dan sinaptogenesis. Studi ini diperjelas dengan studi in vitro lain yang dilakukan oleh Katsuda, et al. yang menjelaskan bahwa penurunan peptida $\mathrm{A} \beta$ terjadi intraseluler dan ekstraseluler, serta ADSC-Exo mengandung enzim neprilysin yang merupakan endopeptidase neuron (NEP). Enzim ini dapat mendegradasi peptida $A \beta$ sehingga terjadi penurunan. Selain itu, studi ini juga menemukan bahwa ADSC-Exo dapat melebur dengan cell line N2a yang merupakan model sel Alzheimer. Hal ini juga menjelaskan penemuan mengenai penurunan peptida $A \beta$ intraseluler. Studi berlanjut ke tahap in vivo yang dilakukan oleh Ma T, et al. menginjeksi ADSC tikus (mADSC) secara intraserebral terhadap model tikus transgenik APP/PS1. Studi ini menemukan bahwa mADSC dapat memproduksi sitokin antiinflamasi berupa IL-4 dan protein arginase I. Penemuan pada studi ini berupa aktivasi mikroglia dengan fenotipe antiinflamasi pada otak serta peningkatan kapasitas degradasi peptide $\mathrm{A} \beta$ mikroglia. Dampak hasil dari penemuan tersebut meningkatkan kemampuan kognitif dan penurunan signifikan deposit peptida $\mathrm{A} \beta$ pada hipokampus dan korteks IL-4 dan protein arginase I. Penemuan pada tikus. Kekurangan studi ini yang bersifat invasif karena memerlukan injeksi intraserebral diperlengkap dengan studi in vivo yang dilaksanakan Kim S, et al. dan $\mathrm{Ha}$ $\mathrm{S}$, et al. yang menemukan injeksi intravena pada model tikus Alzheimer dapat menembus sawar darah otak karena adanya kebocoran sawar darah otak akibat Alzheimer.

Studi Ma T, et al. juga diperlengkap dan didukung oleh studi in vivo Kim S, et al. yang menemukan hADSC dapat menurunkan konsentrasi peptida $A \beta$ dan APP-CT pada korteks dan hipokampus, menginduksi produksi NEP, sitokin antiinflamasi IL-10, faktor neurotropik vascular endothelial growth factor (VEGF), dan peningkatan stabilitas sinaps dan dendrit. Penemuan-penemuan tersebut menjelaskan penemuan Kim S, et al. yang menemukan peningkatan kemampuan spasial pada model tikus Studi Ma T, et al. juga Alzheimer yang diberikan hADSC. Berbagai penemuan pada studi in vitro maupun in vitro telah didukung oleh uji klinis fase I yang dilaksanakan Duma C, et al. Uji klinis fase I tersebut mendapatkan peningkatan kognitif dan stabilitas pasien, serta penurunan P-tau dan perbaikan rasio $\mathrm{A} \beta$ terhadap total tau pada pasien yang dilakukan intervensi dengan stromal vascular fraction (SVF) yang mengandung lebih sedikit ADSC. Penemuan ini cukup menjanjikan bagi ADSC karena SVF yang mengandung lebih sedikit ADSC dapat menghasilkan hasil yang cukup memuaskan.

Studi in vivo PRP yang dilakukan oleh Anitua, et al. meneliti mengenai potensi PRP dari subjek manusia dari berbagai kalangan umur terhadap model tikus transgenik APP/PS1. Studi ini menemukan bahwa PRP dapat meningkatkan viabilitas neuron saat terpajan peptida A $\beta 42$, meningkatkan neurogenesis dihipokampus, dan menurunkan neurodegenerasi. Selain itu, studi ini menemukan bahwa potensi efikasi PRP tidak terpengaruh usia dan status Kesehatan subjek sehingga PRP memiliki potensi untuk dimanfaatkan berbagai kalangan usia. 


\section{KESIMPULAN DAN SARAN}

\section{Kesimpulan}

Berdasarkan analisis berbagai studi mengenai ADSC dan PRP, potensi keduanya cukup menjanjikan walaupun PRP masih belum banyak yang meneliti potensinya pada penyakit Alzheimer. Secara keseluruhan, ADSC dan PRP memiliki sifat neuroprotektif dan neuroregeneratif, melalui berbagai mekanisme seperti penurunan konsentrasi peptida $A \beta$, pertumbuhan neuron dan Synaptogenesis aktivasi mikroglia dengan fenotipe antiinflamasi, peningkatan produksi sitokin antiinflamasi, peningkatan stabilitas sinaps dan dendrit, peningkatan viabilitas neuron, peningkatan neurogenesis dan penurunan neurodegenerasi sehingga terjadi peningkatan kemampuan kognitif.

\section{Saran}

Studi lebih lanjut mengenai kedua factor bioaktif tersebut diperlukan untuk menemukan potensi lebih lanjut. Potensi PRP untuk menginduksi sel progenitor neuron sehingga memiliki potensi untuk menjadi faktor bioaktif yang dapat mengaktivasi ADSC dan meningkatkan potensi neuroregeneratif serta neuroprotektif ADSC. Kemungkinan kombinasi terapi ADSC dan PRP untuk penanganan penyakit Alzheimer juga perlu dipelajari lebih lanjut.

\section{DAFTAR PUSTAKA}

1. Bondi MW, Edmonds EC, Salmon DP. Alzheimer's disease: past, present, and future. J Int Neuropsychol Soc. 2017 Oct;23(9-10):818- 831.

2. Yiannopoulou KG, Papageorgiou SG. Current and future treatments in alzheimer disease: an update. J Cent Nerv Syst Dis. 2020 Feb 29;12:1179573520907397.

3. Alzheimer's Association. 2018 alzheimer's disease facts and figures. Alzheimer's \& Dementia. 2018 Mar;14(3): 367-429.

4. Prince M, Bryce R, Albanese E, Wimo A, Ribeiro W, Ferri CP. The global prevalence of dementia: a systematic review and metaanalysis. Alzheimers Dement. 2013 Jan;9(1):63-75.e2.

5. Prince, Martin, Comas-Herrera, Adelina, Knapp, Martin, Guerchet, Maëlenn and Karagiannidou, Maria. World Alzheimer report 2016: improving healthcare for people living with dementia: coverage, quality and costs now and in the future. London(UK): Alzheimer's Disease International; 2016.

6. Reitz C, Brayne C, Mayeux R. Epidemiology of Alzheimer disease. Nat Rev Neurol. 2011 Mar;7(3):13752.

7. Weller J, Budson A. Current understanding of Alzheimer's disease diagnosis and treatment. F1000Res. 2018 Jul 31;7:F1000 Faculty Rev1161.

8. Del-Aguila JL, Koboldt DC, Black K, Chasse R, Norton J, Wilson RK, Cruchaga C. Alzheimer's disease: rare variants with large effect sizes. Curr Opin Genet Dev. 2015 Aug;33:49-55.

9. Nisa H, Sinuraya RK. Biomarker miRNA-146a sebagai deteksi dini yang efektif untuk Alzheimer. Farmaka. 2017; 15(2):159-177. 
10. Budson AE, Solomon PR. New criteria for Alzheimer disease and mild cognitive impairment: implications for the practicing clinician. Neurologist. 2012 Nov;18(6):356-63.

11. Yiannopoulou KG, Papageorgiou SG. Current and future treatments in alzheimer disease: an update. J Cent Nerv Syst Dis. 2020 Feb 29;12:1179573520907397.

12. Atri A. Current and Future Treatments in Alzheimer's Disease. Semin Neurol. 2019 Apr;39(2):227-240.

13. Kishita N, Backhouse T, Mioshi E. Nonpharmacological Interventions to Improve Depression, Anxiety, and Quality of Life (QoL) in People With Dementia: An Overview of Systematic Reviews. J Geriatr Psychiatry Neurol. 2020 Jan;33(1):28-41.

14. Mossello E, Ballini E. Management of patients with Alzheimer's disease: pharmacological treatment and quality of life. Ther Adv Chronic Dis. 2012 Jul;3(4):183-93.

15. FanL,MaoC,HuX,ZhangS, YangZ,HuZ , Sun H, Fan Y, Dong Y, Yang J, Shi $\mathrm{C}, \mathrm{Xu} \mathrm{Y}$. New Insights Into the Pathogenesis of Alzheimer's Disease. Front Neurol. 2020 Jan 10;10:1312.

16. Yiannopoulou KG, Papageorgiou SG. Current and future treatments for Alzheimer's disease. Ther Adv Neurol Disord. 2013 Jan;6(1):19-33.

17. Yiannopoulou KG, Papageorgiou SG. Current and Future Treatments in Alzheimer Disease: An Update. J Cent Nerv Syst Dis. 2020 Feb 29;12:1179573520907397.

18. Kaushal V, Dye R, Pakavathkumar P, Foveau B, Flores J, Hyman B, Ghetti B, Koller BH, LeBlanc AC. Neuronal NLRP1 inflammasome activation of Caspase-1 coordinately regulates inflammatory interleukin-1-beta production and axonal degenerationassociated Caspase-6 activation. Cell Death Differ. 2015 Oct;22(10):167686.

19. Dubey NK, Mishra VK, Dubey R, Deng Y, Tsai F, Deng W. Revisiting the advances in isolation, characterization, and secretome of adipose- derived stromal/stem cells. Int J Mol Sci. 2018;19(8):2200.

20. Hong P, Yang H, Wu Y, Li K, Tang Z. The functions and clinical application potential of exosomes derived from adipose mesenchymal stem cells: a comprehensive review. Stem Cell Res Ther. 2019;10(1):242.

21. Bacakova L, Zarubova J, Travnickova M, Musilkova J, Pajorova J, Slepicka $P$, et al. Stem cells: their source, potency and use in regenerative therapies with focus on adiposederived stem cells - a review. Biotechnol Adv. 2018;36(4):1111-26.

22. Cavallo C, Roffi A, Grigolo B, Mariani E, Pratelli L, Merli G, et al. Plateletrich plasma: the choice of activation method affects the release of bioactive molecules. Biomed Res Int. 2016;2016:1-7.

23. Shen YX, Fan ZH, Zhao J, Zhang P. The application of platelet-rich plasma may be a novel treatment for central nervous system diseases. Med Hypotheses. 2009;73(6):1038- 40.

24. Farrukh A, Zhao S, del Campo A. Microenvironments designed to support growth and function of neuronal cells. Front Mater. 2018;5:122.

25. LeeM,BanJJ,YangS,ImW,KimM.The exosome of adipose-derived stem cells reduces $\beta$-amyloid pathology and apoptosis of neuronal cells derived 
from the transgenic mouse model of Alzheimer's disease. Brain Res. 2018 Jul 15;1691:87-93

26. Katsuda T, Tsuchiya R, Kosaka N, Yoshioka Y, Takagaki K, Oki K, Takeshita F, Sakai Y, Kuroda M, Ochiya T. Human adipose tissuederived mesenchymal stem cells secrete functional neprilysin-bound exosomes. Sci Rep. 2013;3:1197.

27. Ma T, Gong K, Ao Q, Yan Y, Song B, Huang H, Gong Y. (2013). Intracerebral Transplantation of Adipose-Derived Mesenchymal Stem Cells Alternatively Activates Microglia and Ameliorates Neuropathological Deficits in Alzheimer's Disease Mice. Cell Transplantation. 2013 Jan 1; 113-126.

28. Kim S, Chang KA, Kim Ja, Park HG, Ra JC, Kim HS, Suh YH. The preventive and therapeutic effects of intravenous human adipose-derived stem cells in Alzheimer's disease mice. PLoS One. 2012;7(9):e45757.

29. Ha S, Ahn S, Kim S, Joo Y,Chong YH, Suh YH, Chang KA. In vivo imaging of human adipose-derived stem cells in Alzheimer's disease animal model. J Biomed Opt. 2014 May;19(5):051206.

30. Duma C, Kopyov O, Kopyov A et al. Human intracerebroventricular (ICV) injection of autologous, nonengineered, adipose-derived stromal vascular fraction (ADSVF) for neurodegenerative disorders: results of a 3-year phase 1 study of 113 injections in 31 patients. Mol Biol Rep. $2019 \mathrm{Jul}$ 20; 46: 5257- 5272

31. Anitua E, Pascual C, Pérez-Gonzalez R, Antequera D, Padilla S, Orive G, Carro E. Intranasal delivery of plasma and platelet growth factors using PRGF-Endoret system enhances neurogenesis in a mouse model of Alzheimer's disease. PLoS One. 2013 Sep 19;8(9):e731. 